\title{
Resente Matteusnavorsing in Suid-Afrika
}

\author{
H J B Combrink \\ Universiteit van Stellenbosch
}

\begin{abstract}
Recent Matthean-research in South Africa

This article deals with recent developments in Matthean research, mostly by members of the New Testament Society of South Africa. Initially, research on Matthew was influenced to a large degree by discourse analysis. Literary criticism and narratology also made an impact on this research, as well as speech-act theory, pragmatics and rhetoric. Social-scientific criticism also played a role, and the Sermon on the Mount has also been read as littérature engagée. Recently, the specific contribution of Matthew to the subjects of Theology and Ethics has also received attention. A growing sensitivity to the South African and the broader African context is also currently being seen..
\end{abstract}

\section{INLEIDING}

Dit is enigsins moeilik om 'n terminus a quo vas te stel vir die omskrywing van die attribuut 'resent' in die titel van hierdie bydrae. Aangesien die doel van hierdie konferensie* kennelik is om in 'n mate ' $n$ oorsig te gee van wat in die jare van minder goeie kontak plaasgevind het, lyk dit sinvol om veral op die navorsing op

\footnotetext{
* Die onderhawige artikel is 'n geredigeerde weergawe van 'n referaat gelewer by gelecnlheid van 'n simposium tussen Nederlandse en Suid-Afrikaansc Nuwe-Testamentici gehou op 2-3 Augustus 1993, Utrecht, Nederland. Finansiële ondersteuning deur die SWO van die RGN vir navorsing in verband met hierdie artikel word hiermee met dank erken. Die menings wat in hierdie publikasic gehuldig word, asook die bevindinge van die ondersoek, is die van dic outeur en mag nie as die van die SWO of RGN beskou word nie. Dit is ' $n$ besondere voorreg om hierdie bydrae in hierdie feesbundel te mag publisecr vit erkentlikheid vir dic besondere bydrae wat HTS lewer tot die beoefening van die teologic in Suid-Afrika.
} 
Matteus sedert die sewentigerjare te konsentreer. Ofskoon dit vanselfsprekend is dat daar wel oor en weer kennis geneem is van wat gepubliseer is, bied 'n simposium soos hierdie wel die geleentheid om bepaalde tendense, wat moontlik aan te wys is, verder te kan bespreek.

'n Verdere inleidende opmerking is dat die gang van die Matteusnavorsing waarskynlik die algemene tendense wat reeds in hierdie konferensie uitgelig is, sal weerspieël. Tog kan dit interessant wees om iets van die storie van Matteus in die Suid-Afrikaanse navorsing die afgelope jare te volg.

Van Aarde bied reeds in 1984 in Scriptura 'n oorsig van die navorsing op die gebied van die Matteusevangelie. Hierdie oorsig is egter nie in die eerste plek spesifiek afgestem op die situasie in Suid-Afrika nie, en behandel in elk geval alleen die ontwikkelinge tot in die vroeë tagtigerjare. In hierdie oorsig sluit hy aan by die bekende opeenvolgende fases van Nuwe-Testamentiese navorsing (literêre kritiek, vorm- en tradisiegeskiedenis en redaksiegeskiedenis gevolg deur nuwere ontwikkelinge) en toon aan hoe die verskuiwinge in hierdie verband sy neerslag vind op die terrein van die Matteusnavorsing in die algemeen, maar ook wat Suid-Afrika betref. Hierdie artikel bring dus reeds die eerste gedeelte van die periode onder diskussie op kaart, maar dit is interessant om die vervolg van die neerslag van die voortgaande metodologiese debat op die Matteusnavorsing na te gaan.

Hoewel die statistiek nie $100 \%$ volledig is nie, is dit interessant dat daar in die periode 1929-1960 dertien titels van publikasies oor Matteus aan te wys is, twaalf in die periode 1961-1976, dan vyftien in 1977, drie vanaf 1978 tot 1981, en dan honderd en nege in die periode 1982-1991. 'n Deel van die aantal publikasies in die laaste dekade is onder meer toe te skryf aan die negentien bydraes wat as preekriglyne in Woord teen die Lig verskyn het, maar dit is duidelik dat daar 'n besondere toename in publikasies oor Matteus te bespeur is. Dit korreleer waarskynlik goed met die stygende lyn op die gebied van Nuwe-Testamentiese publikasies wat in die algemeen in die laaste jare aan te wys is. ' $n$ Verdere gedeeltelike verklaring is die twee kongresse wat die Nuwe-Testamentiese Werkgemeenskap van Suid-Afrika aan Matteus in 1977 en weer in 1982 gewy het (vgl Neotestamentica 11 en 16).

\section{MEER TRADISIONELE BENADERINGS TOT MATTEUS}

Soos reeds gesé, beklemtoon Van Aarde vermeldenswaardige resultate op die gebied van Matteus van die verskillende metodologiese benaderings wat in die loop van die tyd in die Nuwe-Testamentiese navorsing in die algemeen in swang was. In Suid-Afrika het die tipiese tradisiehistoriese en vormhistoriese benaderings nie werklik ' $n$ beduidende invloed op Matteusnavorsing gehad nie. Dit hang waarskynlik saam met die bedugtheid wat in daardie jare ten opsigte van hierdie metodes die 
toneel van Nuwe-Testamentiese navorsing beheers het.

Een van die tipiese kenmerke van Matteus wat reeds deur die literêr-kritiese (of bronnehistoriese) benadering aan die orde gestel is, is die vervullingsitate (Reflexionszitate) wat eie is aan Matteus. Hierdie sitate word juis van die ander in Matteus onderskei deur die wyse waarop die vervulling van die Ou Testament hierin sentraal figureer. Waar hierdie kwessie aan dic orde kom, is dit veral as deel van Matteus se redaksionele aktiwiteit (Combrink 1979:53; vgl ook Willemse 1985). Trouens, die vervullingsitate is 'n belangrike faset van die Christologie van Matteus. Dit is duidelik dat die wyse waarop dit in die diskussie aan die orde kom, veral in aansluiting by die redaksiehistoriese benadering is waarvolgens daar veel meer aandag aan die teologiese inset van die evangelis as in die voorafgaande metodes bestee word.

Oor die geheel het die redaksiehistoriese benadering 'n veel positiewer ontvangs in die Suid-Afrikaanse navorsing geniet as sy voorgangers. Dit hang waarskynlik saam met die feit dat die redaksiehistoriese benadering die geleentheid gebied het om meer op Matteus as geheel en veral op die teologie van Matteus te kon konsentreer. Tog moet opgemerk word dat weinig Suid-Afrikaanse Nuwe Testamentici werklik konsekwent redaksiehistories te werk gegaan het (maar kyk veral die proefskrif van $H$ C van $Z y l, 1987$, waarvan 'n aansienlike gedeelte aan 'n redaksie-historiese bespreking van Mt 18 gewy is). Dit was meer 'n geval van dat aansluiting gevind is by redaksiehistoriese studies oor Matteus wat verskyn het, en van wie se insigte dan gebruik gemaak is in 'n poging om die debat oor die teologie van Matteus verder te voer.

Hierdie wyse van gedeeltelike en selektiewe aansluiting by die bevindinge van die historiese kritiek en sy metodes soos gangbaar aangewend, vind onder meer sy neerslag in die uiteensetting van die 'Inleiding en Teologie van Matteus' in die Handleiding by die Nuwe Testament, IV (Combrink [1980]). Die aanpak van beide gedeeltes oor die 'Inleiding en die Teologie van Matteus' is redelik tradisioneel van aard.

Wat die opbou en eenheid van die evangelie betref, word daar hier gekies vir 'n simmetriese of chiastiese struktuur waarin die vyf redevoeringe van Jesus 'n belangrike strukturerende rol speel (Combrink 1988c:80). Terwyl daar erkenning gegee word aan die ander ordeningsbeginsels wat aangewys sou kon word (soos dro

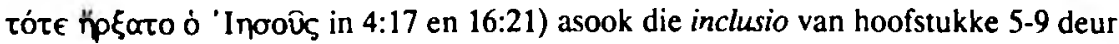
4:23 en 9:35, word tog geoordeel dat die simmetriese of konsentriese patroon met Mt 13 as 'n draaipunt wel bepaalde voordele as ordeningsprinsipe inhou. Daar word verder afgelei dat Jesus se redevoeringe volgens Matteus eintlik aan die adres van die dissipels gerig is, terwyl dit inhoudelik handel oor Jesus se verhouding tot die Joodse skare (vgl Van Aarde 1982b:125v). 
Hoewel in dieselfde volume in die artikel oor 'Die sinoptiese vraagstuk' wel ingegaan word op die resente oplewing van die Griesbach-hipotese waarvolgens die prioriteit van Matteus voorgestaan word, word die standpunt gehandhaaf dat Matteus ná Markus gedateer moet word (Combrink 1988c:74). Hoewel die literatuur waarna verwys word, werke soos die van Frankemölle (1974) insluit waarin bepaalde nuwere tendense reeds aan te wys is, is dit duidelik dat die bydrae oor die 'Teologie van Matteus' grotendeels berus op die gangbare redaksiehistoriese bydraes wat in daardie tyd aan die orde van die dag was. In die verbygaan moet daarop gewys word dat die bydrae deur W S Vorster oor Markus in dieselfde volume van die Handleiding egter reeds die verhalkarakter van die evangelie volledig verdiskonteer het ten opsigte van sowel die 'Inleiding as die Teologie'.

Tog moet ook daarop gewys word dat in die bespreking van die teologie van Matteus daar nie bloot op tipies redaksiehistoriese wyse alleen uitgegaan is van die eie redaksionele stof wat in Matteus aan te wys is nie, maar daar is ook beklemtoon

dat die evangelie as literêre werk in sy geheel beskou moet word. Die redaksiehistoriese bevindinge moet dus korreleer met 'n visie van die evangelie as geheel, wat weer verband hou met ' $n$ insig in die struktuur, styl en wyse waarop die skrywer van sy bronne gebruik maak.

(Combrink 1988c:81)

Hierdie aksente is in ooreenstemming met stemme wat elders opgaan:

Matthew's theology...'as a totality' depends on his gospel as a whole and not solely on what is distinctive in his editorial arrangement, alterations and so forth. Redaction-criticism has justly been criticized for building massive theological hypotheses on very tiny pieces of editorial evidence.

(Hill 1979:139)

Op hierdie insigte sou later meer konsekwent voortgebou kon word na gelang die insigte van die literêre kritiek (in die eintlike sin van die woord) meer konsekwent in die Matteusnavorsing deurgewerk het.

Daar moet egter ook daarop gewys word dat die insigte van die historiese kritiek - al gebeur dit in 'n sekere sin veel later en meer insidenteel as in Europa - tog ook in die Matteusnavorsing reflekteer. Hier kan verwys word na die bydrae van Van Aarde (1986) oor die vermeerdering van die brood. Aan die hand van hierdie perikoop probeer Van Aarde om die histories-kritiese vraagstelling in perspektief te plaas en aan te toon dat daar nie 'n spanning tussen geloof en historiese kritiek hoef te bestaan nie. In die proses kom hy ook tot belangrike bevindinge in verband met die messiaans-eskatologiese maaltyd-motief en die intermediêre funksie van die 
dissipels (Van Aarde 1986:251v). Vorster het reeds in 1971 met 'n vraagstelling ontleen aan die historiese kritiek die kwessie van Jona in Mt 12 aan die orde gestel. Hy is egter ook van mening dat die beginsels van historiese beoordeling geen afbreuk doen aan die gesag van die Skrif nie (Vorster 1971:235). Tog toon hy aan dat Matteus van Markus en $\mathrm{Q}$ gebruik gemaak het, en wys hy ook op die spesifiek bedoeling van Matteus met die rangskikking van sy stof.

Inhoudelik word daar in hierdie fase van die navorsing natuurlik op sekere belangrike kwessies ingegaan, soos die aard van die getuienis van die kerk in die wêreld volgens Mt 5:13-16 (Du Toit 1966), die selfopenbaring van Jesus volgens Mt 5-7 (Du Toit 1967) en die maagdelike geboorte van Jesus volgens die Matteus-evangelie (Koekemoer 1971).

\section{DISKOERSANALISE}

Intussen het die beoefening van die struktuuranalise/diskoersanalise (of strukturele eksegese in onderskeiding van strukturale eksegese - Vorster 1982:135, 139) in SuidAfrika onder die invloed van veral JP Louw (vgl 1982) vinnig veld gewen. Om die metode prakties toe te pas, word twee kongresse van die Nuwe-Testamentiese Werkgemeenskap van Suid-Afrika in 1977 en 1982 aan die strukturele ontleding van die Matteusevangelie gewy, waarvan die resultate in Neotestamentica 11 en 16 onderskeidelik gepubliseer word.

Uiteraard is daar reeds in 1977 nogal verskil in aanpak aan te wys tussen die onderskeie referate. Tog sou beweer kan word dat in hierdie beginfase die aandag baie sterk op die afbakening van kola en die aanwys van die oppervlakte-struktuur val. Tog is dit belangrik om spesifiek op die bydrae van Maartens (1977) te let aangesien hy bewustelik aansluit by die diskussie in die Algemene Taalwetenskap en Algemene Literatuurwetenskap. Hy bestee derhalwe aandag aan sake soos topikalisasie en fokus, asook sintagmatiese vooropstelling en ekstra patroonvorming (Maartens 1977: 50, 51). Daar kan waarskynlik met reg beweer word dat hierdie referate in bepaalde opsigte tog waardevolle insigte ten opsigte van die Matteusevangelie blootgelê het. lets wat hopelik vir die leser van die Griekse teks wel van waarde is, is die Addendum waarin die indeling van die Griekse teks in kola gebied word.

In die tweede uitgawe van Neotestamentica (1982) wat aan Matteus gewy is, kom ander tendense na vore. Nou word daar aan die makrostruktuur van Matteus aandag gegee (Combrink 1982). Daar word aandag bestee aan die literêre en retoriese tegnieke wat aangewend word om globale en makrostrukture mee af te baken. Die konsentriese of simmetriese opbou van Matteus word hier weer sterk onderstreep. Dit word egter duidelik in hierdie uitgawe van Neotestamentica dat die 
insigte van die literêre kritiek, spesifiek die narratologie, steeds meer 'n rol begin speel. Daar word met ander woorde nie bloot op grond van die kolonstruktuur geredeneer nie, maar die insigte van die literatuurwetenskap speel 'n steeds groter rol. Vergelyk in hierdie verband die bydrae van Van Aarde (1982:32) waarin hy klem lê op die spanning wat in die verhaal ontstaan deur die karakterisering van die dissipels wat konsekwent uitgebeeld word as mense wat wel insig het, maar ook klein van geloof is.

In De Villiers se bydrae (1982) word ook pertinente aspekte van die narratiewe karakter van Matteus behandel, te wete die literêre karakters in Mt 19-22 en die bydrae wat sodoende gelewer word tot die ontwikkeling van die plot van Matteus. 'Mt 19-22 with its characterisation of the crowds and the Jewish leaders thus continues and foreshadows important aspects of the plot in Matthew' (De Villiers 1982:65).

Ofskoon geen Suid-Afrikaners nie, verskyn in dieselfde jaar die bydrae van Clark \& De Waard (1982) in Scriptura S1, wat dus besonder sinvol aansluit by die diskussie wat in die Nuwe-Testamentiese Werkgemeenskap van Suid-Afrika aan die gang is en in Neotestamentica 16 gereflekteer word. Ongelukkig is daar op daardie tydstip weinig interaksie tussen hierdie publikasies, juis vanweë die feit dat dit feitlik gelyktydig verskyn. Clark \& De Waard bied in elk geval ook 'n analise van die evangelie as geheel vanuit 'n linguistiese perspektief, sonder om die waarde van ander benaderings daarmee te wil ontken. Terwyl hulle insigte in verskillende opsigte aansluit by ander bekende standpunte, onderskei hulle drie bedrywe in Matteus as geheel. Die aanleiding hiertoe is veral geleë in die opsigtelike tekstuele binding tussen 4:23 en 9:35. Vanuit hierdie beginpunt konstrueer hulle dan drie bedrywe:

I Narratief hfst 1-4 '

Diskoers 5-7

Narratief $8-9$

II Diskoers 10

Narratief 11-12

Diskoers 13

Narratief 14-17

Diskoers 18

III Narratief 19-22

Diskoers 23-25

Narratief 26-28. 
Uiteindelik is hulle konklusie: 'Thus the gospel as a whole has an impressive unity of structure, theme and movement which is not fully apparent when only shorter sections are under consideration' (Clark \& De Waard 1982:77).

Die Tyndale Nuwe-Testamentiese lesing van 1982, wat in dieselfde tyd as die vorige bydraes ontstaan (Combrink 1983), stel ook spesifiek die struktuur van Matteus as verhaal aan die orde. Hier word pertinent aan die vraag aandag gegee of die dikwels waargenome simmetriese of konsentriese bou van Matteus hoegenaamd met die struktuur van die evangelie as verhaal te verenig is. Die bevinding is dat die tipiese opbou van 'n verhaal, te wete Plasing (1:1-4:17), Komplikasie (4:1825:46) en Resolusie (26:1-28:20) op 'n merkwaardige wyse saamval met die konsentriese opbou van Matteus (Combrink 1983:75).

Die insigte van Kingsbury (1975:36v, 161v) ten opsigte van die belang van die

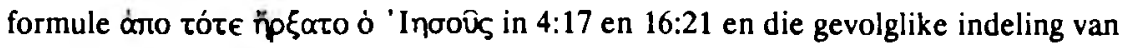
die evangelie in drie hoofdele bring wel mee dat hoofstuk 13 nie meer spesifiek as die wentelpunt van die verhaal gesien word nie, maar dat eerder van die hele gedeelte 11:2-16:20 gepraat word 'as a major turning area of the narrative' (Combrink 1983:83). In hierdie bydrae word daar ook reeds aandag gevra vir die pragmatiese aspekte van die teks as 'n uitdaging aan die leser om gehoor te gee aan die oproep en opdrag tot sending van Jesus aan sy dissipels, maar tegelyk ook vir die waarskuwings in die teks as waarskuwings aan die leser self.

\section{AANDAG AAN MEER AS NET DIE IMMANENT-SINTAKTIESE EN OUTOSEMANTIESE ASPEKTE VAN DIE TEKS}

Dit word konkreet geillustreer aan die hand van artikels deur Van Aarde ten opsigte van die makarismereeks in die Bergrede. Hierin gaan hy krities in op die voorstelle van Wolfgang Richter, en kies dan vir die onlosmaaklike eenheid van vorm en inhoud ten opsigte van Gattungforschung. Teenoor die sogenaamde metodepluralie van mense soos Richter, beklemtoon Van Aarde die voortgaande waarde van die historiese kritiek as 'n selfstandige benadering tot die teks (kyk ook $\mathrm{H}$ C van Zyl 1982 se studie van Mt 7:6 waarin historiese kritiek en immanante eksegese met mekaar gekombineer word). Hy sien ook die funksie van 'n Gattung as die verhouding tussen die Sitz im Leben en die Sitz in der Literatur (Van Aarde 1980a:67). Daar moet dus onderskei word of die Gattung funksioneel-tipies of funksioneelatipies in 'n bepaalde geval gebruik is. Waar hy aantoon dat die makarisme 'n religieuse geluk-aankondiging is wat verband hou met die eskatologiese heil, pas die reeks besonder goed by die breër konteks van 4:23-9:35 se didaktiese, kerugmatiese en genesingsmotiewe (Van Aarde 1982a:48vv). Dit beteken dat hierdie Gattung in die betrokke konteks besonder effektief en funksioneel aangewend word. 
Daar moet veral ook op die gebruik van die makarismes gelet word en nie alleen op die betekenis nie. Dit is dan wat die Messiaanse heilgerigte en eskatologiese strekking teen die agtergrond van Jesaja 61 na vore bring. Hierdie heilsaankondiging geld vir mense met ' $n$ gesindheid en 'n optrede waarvan teen die rabbynse Jodedom polemiek gevoer word en mense op 'n paradoksale wyse gelukkig geprys word (Van Aarde 1980b:23). Juis die insig in die geskiedenis van die makarismes beklemtoon dat mens nie alleen sinkronies te werk moet gaan nie, maar ook diakronies. Van Aarde beklemtoon dat die makarismereeks in elk geval as die exordium van die Bergrede as geheel gesien moet word. Hierop word later weer teruggekom.

\section{DIE INVLOED VAN DIE LTTERARE KRITIEK EN NARRATOLOGIE}

Gaandeweg vind daar 'n verskuiwing plaas as gevolg van die groter wordende invloed van die literère kritiek op Nuwe-Testamentiese navorsing in SA, en word daar steeds meer erns gemaak met die narratologiese dimensies van Matteus. Daar is reeds hierbo gewys op navorsing ten opsigte van die struktuur van Matteus as verhaal.

In die proefskrif van Van Aarde (1982) word daar sterk aangesluit by die werk van Boris Uspensky met sy beklemtoning van die viervoudige verhaalsperspektief. Van Aarde behandel die vertellersperspektief op ideologiese, fraseologiese, tyds- en topografiese vlak, maar gaan nie so spesifiek in op die psigologiese vlak nie. Hy wys duidelik uit hoe die onderskeie karakters bydra tot die konstituering van die plot van die verhaal: Jesus as die protagonis, Johannes die Doper as die prototipe van die protagonis, die Joodse leiers as antagonis, die Joodse skare en heidene as adres van die sending en die dissipels as die veronderstelde helpers van die protagonis.

Ook andere lewer in hierdie opsig 'n bydrae. So bespreek De Villiers (1982) die literère akteurs naamlik die skare, die dissipels, die Joodse leiers en Jesus in Mt 19-22. Hy wys ook op die bydrae van die karaktertekening tot die plot van die verhaal, terwyl hy ook die belang van die funksionering van die Christologiese titels in hierdie hoofstukke uitwys. Veral Van Aarde in sy bydrae (1987) oor 'Funksionele Jesusbenaminge in die Matteusevangelie' as vertelling beklemtoon in aansluiting by Uspensky die funksionaliteit van benaminge in vertelliteratuur. Terwyl titels vroeër in die Christologie beslis 'n belangrike, selfs eensydige rol gespeel het, was die klem steeds op die geskiedenis en die aanwysing van een sentrale titel, en nie op die narratiewe karakter van die evangelie nie. Hoewel hy met Kingsbury saamstem dat Seun van God 'n besonder belangrike titel in Matteus is, is hy wel krities ten opsigte van Kingsbury se oorbeklemtoning daarvan. 
Van besondere belang is die identifisering van die ideologiese perspektief van Immanuel, God met ons, as die basiese motief van Matteus. Hy lei verder af dat daar ' $n$ analogie is tussen die sending van Jesus voor Pase, en die sending van die dissipels na Pase wat die twee konstitutiewe handelingslyne van die vertelling vorm.

\section{STRUKTURALISME/STRUKTURALE EKSEGESE}

Hierbo is reeds gewys op die onderskeiding tussen die sogenaamde strukturele en strukturale eksegese. In die geval van laasgenoemde gaan dit om die werk van die Franse strukturalisme wat veral sterk deur Greimas bepaal is.

In Suid-Afrika het hierdie rigting weining aandag getrek (vgl Combrink 1988a). In 'n artikel oor die bruikbaarheid van die aktante-analise oordeel Van Aarde (1980c) dat die Sinoptiese eksegese tog in bepaalde opsigte by hierdie benadering gebaat het. In hierdie verband verwys hy na die waarneming deur verskeie redaksiehistoriese navorsers van die rol wat groepe in die Matteusevangelie speel. In hierdie verband meen hy kan die vasstelling van die aktansiële relasies sonder twyfel van waarde wees. Terwyl reeds gewys is op die soms byna willekeurige aanwysing van verskillende titels in Matteus as die belangrikste, meen hy dat ook in hierdie verband die aktansiële analise as 'n korrektief gesien kan word (Van Aarde 1980c:42). Verder vind hierdie benadering geen pertinente weerklank in die Matteusnavorsing nie.

\section{TAALHANDELINGE, PRAGMATIEK EN RETORIEK - GEİLUSTREER ONDER ANDERE AAN DIE HAND VAN DIE GELYKENISSE EN SA- LIGSPREKINGE}

Nuwere insigte in die gelykenisnavorsing het ook ten opsigte van die Matteusevangelie 'n neerslag gevind. Hier kan gewys word op Vorster se bydrae van 1977 waar hy Mt 13 binne die konteks van die evangelie as geheel aan die orde gestel het. In 1985 keer hy weer na die problematiek van Mt 13 terug om die bestudering van gelykenisse in isolasie af te wys en klem te lê op die taalhandeling wat met 'n gelykenis uitgevoer kan word. Volgens hom gee die gelykenisse van Mt 13 aan die leser insig oor die koninkryk, maar nooi haar ook uit om deel te kry aan daardie vertelde wèreld (Vorster 1985:163).

Du Plessis (1985:179-209) wy 'n breedvoerige bespreking aan Mt 13 in sy proefskrif oor die helderheid en verborgenheid van die gelykenisse. Hy doen dit binne die breë raamwerk van die gelykenisse as kommunikasie-strategie in die evangelies. Hierin sluit hy veral aan by die taalhandelingsteorie, soos deur Leech (1983) uitgebou. Hy toon die betekenis aan van tekste soos Mt 13:11 waarin die herstel van die bedreigde kommunikasie tussen Jesus en die dissipels gekonstrasteer word 
met die verbreking van kommunikasie tussen Jesus en 'die ander'. Hier het ons te doen met die beginsels van hoflikheid en koöperasie wat of deurbreek word of ten opsigte van die dissipels wel gehandhaaf word (Du Plessis 1985:181).

Ten opsigte van die bekende crux in Mt 13:10-17, naamlik die doel van die gelykenisse, oordeel hy dat dit nie werklik sin het om op die verskil tussen Matteus se ö $\tau$ en Markus en Lukas se 'va in te gaan nie, omdat die gevolg in elk geval dieselfde is (Du Plessis 1985:186). Die vraag na die finaliteit van Jesus se negatiewe oogmerke met die gelykenisse moet in die breër konteks van die gang van die hoofstuk gesien word. Dan is dit van belang dat die pragmatiese effek van Jesus se gesprek met die dissipels daartoe lei dat hulle behoort te aanvaar dat Jesus die koninkryk deur middel van gelykenisse verkondig, dat hulle moet vertrou dat die sukses van die proklamasie die aanvanklike oënskynlike mislukkings sal oortref, dat hulle mag hoop om meer te ontvang en dat hulle sekuriteit mag belewe omdat God in hulle belang handel (Du Plessis 1985:189). Hulle verhouding met Jesus word versterk en verryk (vgl ook Mt 13:16). Maar dit is ook duidelik dat daar in die gesprek dreigement ten opsigte van 'die ander' geïmpliseer word. Die implisiete leser kry ook verder die boodskap dat die oplaaiende antagonisme teen Jesus nie sal ophou nie en noodwendig op die kruis moet uitloop. Die implisiete leser word egter nie van inligting voorsien ten opsigte van die toekoms van Israel nie. Tog lê die verantwoordelikheid vir die aanvaarding van die boodskap volledig by die leser (vgl Mt 13:9 - 'wie ore het, moet luister'). 'The implied reader is assured that the rejection of Jesus by God's own people did not impede God's purpose or the success of Jesus' mission. The act of reading the gospel signifies a process of growth and harvest which validate the promise made to the disciples' (Du Plessis 1985:196).

Wat die res van die hoofstuk betref, wys hy op die direkte vertellerskommentaar in Mt 13:34v met die vervullingsitaat uit Ps 78:2. Die verteller sien 'n ooreenkoms tussen die verkondiging deur Jesus van God se verborgenhede en die wyse waarop die Psalm die raaiselagtige handelinge van God met Israel aan die orde stel. Op hierdie wyse verskaf die verteller in Mt 13:34v pertinente legitimasie vir Jesus se optrede, terwyl hy ook beklemtoon dat die gelykenisse tog wel as proklamasie gesien moet word (Du Plessis 1985:203).

Ten opsigte van die gelykenisse in die tweede deel van Mt 13 kan daarop gewys word dat die gelykenis van die treknet (verse 47-50) wesenlik as dubbelgelykenis funksioneer tot die verklaring van die gelykenis vall die onkruid (verse 36-43), terwyl dieselfde ook geld van die gelykenisse van die skat (vers 44) en die kosbare pèrel (verse 45-46). Die tweede deel van die gelykenisrede vertoon met ander woorde 'n chiastiese opbou waarin die gelykenisse van die skat en pêrel omraam word deur die verklaring van die onkruid en die gelykenis van die treknet. Wanneer met die taalhandelingsaspekte rekening gehou word, beteken dit 
dat in die deel van die gelykenisrede wat spesifiek tot die dissipels gerig is, die genadige aanbod van die koninkryk van die hemel wat tot handeling moet dring (44-46), omraam word deur die ernstige vermaning aan die dissipels $(36-43 ; 47-50)$ om rekening te hou met die eskatologiese eindoordeel waarby ware en vals dissipels geskei sal word. Dit bevat wel die implikasie dat vals dissipels juis hulle is wat nie deur die grootte van die skat tot handeling beweeg word nie.

(Combrink 1987a:55)

Nog 'n gelykenis in die interpretasie waarvan dergelike insigte 'n rol gespeel het, is die gelykenis van die geldstukke in Mt 25:14-30. Wanneer hier rekening gehou word met die atipiese aspekte en die plot van die gelykenis kom daar tog interessante implikasies na vore. Dit is van die begin af duidelik dat die 'helde' (die eerste twee slawe) die 'wenners' gaan wees, wat deur die resolusie van die gelykenisverhaal bevestig word. Ten opsigte van die 'verloorders', is daar wel 'n element van onduidelikheid aangesien die rol van die deurbringer wat wel in die Hebreër-Evangelie teenwoordig is, hier ontbreek. Die buitengewone bestraffing wat die derde slaaf ontvang, deurbreek ook die beginsel van hoflikheid dat kritiek op ander gematig moet wees. Dit impliseer dat in die wêreld van die koninkryk alleen oormatige gehoorsaamheid en gereedheid genoegsaam is. 'The stress is not on the mere neglect, but on the imperative importance of superfluous obedience and preparedness (Du Plessis 1985:151). Terwyl getroues deur die gelykenis bemoedig en versterk word, word ontroues deur die uitbeelding van oordadige bestraffing tot begrip vir die eise van die koninkryk opgeroep.

Dit is ook interessant om daarop te let dat volgens Du Plessis die volgende tipe plot hier aanwesig is: 'genoeg is nie genoeg nie, slegs meer as genoeg is voldoende; of anders gestel: die klaarblyklike verloorder sal verloor en die kennelike wenner sal wen. Teenoor hierdie plot staan 'n ander tipe, soos in die gelykenis van die arbeiders in die wingerd: die oënskynlike verloorder sal wen' (vgl Combrink 1987b:76). Daar moet dus ook rekening gehou word met die pragmatiese krag van die plot. Wanneer die oënskynlike verloorder wen, word die lesers baie sterk op die genadekarakter van die koninkryk gewys. Wanneer uitgespel word dat 'alleen meer as genoeg voldoende is', is die pragmatiese effek daarvan 'n oproep tot aksie in antwoord op die genadekarakter van die koninkryk. Juis die afwyking van die normale verwagting ten opsigte van die koninkryk kan die geloofwaardigheid van die boodskap van die koninkryk in diskrediet bring. Waarom sal iemand wat die gangbare opvattinge in verband met geregtigheid aanhang, hom laat vind vir die oorvloediger geregtigheid wat by Matteus as norm geld, soos ook in hierdie gelykenis? Terwyl Jesus dringend waarsku in hierdie geiykenis, hoor ons hier tegelyk 'n dringende appèl en oproep tot aanvaarding van die eis tot oorvloediger geregtigheid. 
In 'n poging om insigte van die retoriek vir die vertolking van die Bergrede vrugbaar te maak, is aandag geskenk aan die funksionering van die saligsprekinge in die Bergrede (vgl Combrink 1988b; Burger, Müller \& Smit 1990a:39-48). Hier word ten opsigte van die struktuur van die saligsprekinge aangesluit by die interessante voorstel van Kodjak dat daar nie sprake is van twee groepe van vier saligsprekinge nie, maar drie groepe van twee wat deur saligspreking 1 en 8 omraam word. Daar word ook aandag gevra vir die besondere relasie tussen die saligsprekinge en $\mathrm{Mt}$ 5:13-16. Nadat in die saligsprekinge die paradoksale omkeer van waardes beklemtoon is, word hierdie geseëndes met die metafore van sout en lig beskryf.

Die argument rondom die sout verloop as 'n enthymeem: die basiese premis is dat sout sy smaak verloor en uitgegooi kan word. Dit impliseer dat ander aktiewe substansies ook hulle werking kan verloor. Die sekondêre premis word veronderstel: die mens is ook 'n aktiewe substansie. Slotsom: soos sout kan die mens ook sy effektiwiteit verloor. Die dubbele metafoor van die stad op die berg en die lamp op die staander funksioneer op dieselfde wyse. Die band met die voorafgaande saligsprekinge is hier van die grootste belang. 'Juis omdat hulle goeie dade lei tot die verheerliking van die Vader, word dit duidelik dat hulle, die geseëndes, nou tot 'n seën vir ander word' (Combrink 1988:195).

So voltooi Mt 5:13-16 die retoriese inleiding tot die Bergrede. Op die indikatief van die genadige toesegging van die koninkryk van die hemele aan onwaardiges en ellendiges, volg die imperatief by wyse van die metafore van lig en sout, terwyl daar reeds 'n waarskuwing oor ontrou ook geïmpliseer word.

In sy proefskrif gee $\mathrm{Van} Z \mathrm{Zijl}$ (1991) 'n volledige retoriese analise van die Bergrede. Volgens sy analise moet die retoriese verdeling soos volg gesien word: 5:3-10 exordium, 5:11-16 transitus, 5:17-20 narratio, 5:21-7:12 confirmatio en refutatio, en 7:13-27 peroratio. Terwyl die meeste navorsers Mt 5:13-16 as 'n bepaalde vorm van oorgang tussen die saligsprekinge en die res van die Bergrede sien, neem hy Mt 5:11-16 as 'n eenheid. Ten opsigte van die bekende vraag na die retoriese genre van die Bergrede, verskil hy van Kennnedy en Mack en oordeel hy dat die Bergrede eienskappe van aldrie die antieke retoriese genres vertoon (Van $\mathrm{Zijl}$ 1991:217). Van Zijl wil egter verder gaan en verreken dat genres binne bepaalde ideologiese kontekste funksioneer en ook ideologiese belange dien. Hiermee wil hy verder gaan as net bloot ' $n$ vryblywende retoriese analise, en kies dus doelbewus vir die interpretasie van die Bergrede binne die konteks van betrokke literatuur. 
8. 'N KONTEKSTUELE LEES VAN MATTEUS: BETROKKE LTTERATUUR Hier kan 'n wye reeks bydraes aan die orde kom. Uiteraard weerspieël nie alle bydraes dieselfde metodologiese en hermeneutiese vertrekpunte nie. Trouens, die bydraes wat in die verlede op 'n bepaalde wyse wel met die praktyk van die SuidAfrikaanse konteks rekening gehou het, het dit dikwels juis op 'n metodologies naïewe en ongereflekteerde wyse gedoen. Tog is daar steeds meer bydraes waarin daar bewus met die konteks rekening gehou word. Hoewel die Matteusevangelie nie pertinent hier' $n$ rol speel nie, kan in die verbygaan net gewys word op die bundel opstelle in Scriptura S9 (1991) wat gewy is aan 'Issues in contextual hermeneutics'.

Daar kan wel op enkele bydraes oor Matteus gewys word. So wys Cloete (1985) byvoorbeeld op die noue verband tussen Mt 5:9 en Mt 5:10-12. Na 'n deeglike bespreking van die relevante kwessies ten opsigte van die vertolking van hierdie gedeelte, sluit hy af deur daarop te wys dat die taak van die kerk om dit wat Jesus ingelui het, verder uit te leef besonder moeilik is in 'n konteks waar ongeregtigheid gerugsteun word deur' $n$ subjektiewe belydenis van die Christelike geloof. Die werklike oorgang na 'n nuwe toekoms is dan vir hom te sien in die vervolging en lyding van gelowiges soos Beyers Naude in hierdie situasie (Cloete 1985:48).

Suggit vind aansluiting by die gebrik van radikale swart jeugdiges om mekaar as 'comrade' aan te spreek. Na aanleiding hiervan bespreek hy die betekenis van

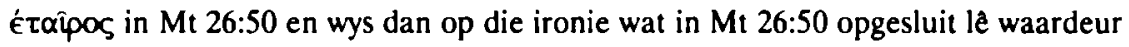
die valsheid van Judas se reaksie op Jesus se liefde en vriendskap onderstreep word. Terwyl Judas se aksie presies die teenoorgestelde as dié van 'n ware kameraad is, 'Jesus, however,...shows himself a true comrade in his ready acceptance of his destiny for the sake of the group' (Suggit 1988:58).

In Jacob (1987) se bydrae oor die uitdaging wat deur vlugtelinge en ballinge aan die kerk gestel word, neem hy sy vertrekpunt in Mt 2:13-15 waaruit hy bepaalde gevolgtrekkinge maak wat volgens hom verband hou met die tema van vlugtelinge en ballinge. Hy sien in die teks verwysings na 'n noodtoestand, informante, gehoorsaamheid aan God en ongehoorsaamheid teenoor die koning, 'n oorlog teen kinders, die veroorsaking van vlugtelinge en die lyding van talle families. Dit is alles terme met ' $n$ besondere geladenheid in die Suid-Afrika van 1987. Dit is egter' $n$ vraag of hiermee werklik reg aan die funksie van hierdie gedeelte in die teks van Matteus as sodanig gedoen is.

In Domeris (1990) se bespreking van die saligsprekinge (Mt 5:1-12) wys hy daarop dat terwyl baie predikers geneig is om net 'n geestelike betekenis in die saligsprekinge te hoor, 'We shall discover that far from being pious platitudes, they are designed to be the reverse - statements which shock the readers/hearers by their 
radical challenge to the contemporary religio-political situation' (Domeris 1990:67). Hy sien dan ook in Mt 5:3 nie 'n verwysing na afhanklikheid van God in die eerste instansie nie, maar 'a collection of poor people, eyes dull with lack of emotion. Poor and without spirit, they are the tired victims of a cruel society' (Domeris 1990:69). Hy sien as die uitdaging van hierdie gedeelte om die werklike wêreld van lyding, verdrukking en ongeregtigheid uit te beeld eerder as die rustige wêreld van die burgerlike middelklas Christendom.

Dit is duidelik dat die rol van die konteks hier tot 'n groter sensitiwiteit gelei het vir wat in die konkrete eerste-eeuse wêreld van die teks afspeel. Domeris (1990:73) spel dan ook die hermeneutiese kwessie hier uit as dié van opponerende ideologieë. Hy gee dan ook toe dat klem op die kontekstuele daartoe lei dat hy God sien as dic verlosser van die armes en gemarginaliseerdes.

In hierdie verband is die voorstel van Van $\mathrm{Zijl}$ (1991) om die Bergrede as littérature engagée te vertolk van besondere belang. Dit beteken dat die teks van die Bergrede as 'n sosio-kulturele diskoers beskou kan word wat meebring dat die interpersoonlike en institusionele dimensies, asook die ideologiekritiese implikasies daarvan onder die loep geneem moet word. Terwyl daar in die Matteusnavorsing oor die algemeen en ook in Suid-Afrika wel aanvoorwerk gedoen is vir 'n 'geëngageerde' interpretasie van die teks, geskied dit egter nie werklik binne 'n volledig verantwoorde hermeneutiese raamwerk nie. In hierdie opsig lui die publikasie van Van Tilborg (1986) oor die Bergrede as ideologiese intervensie 'n nuwe era in. Die proefskrif van Van Zijl is dan ook besonder sterk van die insigte van Van Tilborg afhanklik.

Die Bergrede kan derhalwe nie vertolk word sonder volledige verdiskontering van die sosio-kulturele werklikheid van die tyd van die teks, maar ook van die tyd van die kontemporêre leser nie. Op verskillende maniere reflekteer die teks die sosiale simbole en uiterlike en innerlike tradisies van die eerste-eeuse Joodse maatskappy. Dit is egter 'n werklikheid wat verbandhou met die maatskaplike probleme wat eie was aan daardie tyd. In die Bergrede word daar kontesterend en krities teenoor die geldende ideologie 'n ander toestand in die vooruitsig gestel. Die kritiese gerigtheid teen bepaalde werklikheidspraktyke hang saam met die epideiktiese aard van die teks: telkens kom ons in aanraking met beskuldiging, verwerping en waarskuwing teen bepaalde gesindhede en praktyke (Van Zijl 1991: 291). Tog moet die deliberatiewe aard van die Bergrede ook raakgesien word, aangesien daar deurlopende verwysings is na wat goed en lofwaardig is en oproepe tot die doen van die oorvloediger geregtigheid. Die teks funksioneer ten opsigte van die tyd van sy ontstaan nie alleen krities nie, maar ook normatief-positief. 
Wat van besondere belang is, is om ook te verreken dat wanneer die teks as littérature engagée gelees word, erken moet word dat die sosio-kulturele werklikheid van die tyd van die kontemporêre leser ook volledig 'n rol speel. Dit is dus gebiedend noodsaaklik dat die leser sy eie historiese affiniteit en gebondenheid erken, met ander woorde sy eie verstaanshorison nie veronagsaam nie. Die teks word dus nie 'neutraal' of 'objektief' benader nie, aangesien die verstaanshorison van die leser en sy sosio-kulturele situasie 'n subteks vorm wat die interpretasie beïnvloed. Hierdie verdiskontering van die rol van die eie verstaanwerklikheid moet dus nie alleen normatief-krities nie, maar ook normatief-positief geskied. Dan gaan dit om die eis van die realisering van nuwe familiebande ook in Suid-Afrika op grond van die gehoorsaamheid aan die wil van ons Vader in die hemel. Maar ook by Van Zijl (1991) is daar nog nie werklik gekom tot 'n konkrete betrokke lees van die teks in die konteks van Suid-Afrika en Afrika van die negentigs nie. Wel het hy belangrike hermeneutiese aanwysers gegee om sodanige lees van die teks te fasiliteer.

Wanneer gelet word op die bydraes in twee van die bundels Woord teen die lig wat in 1990 verskyn het (Burger, Müller \& Smit 1990a en 1990b), is dit duidelik dat daar nog steeds 'n verskil is tussen die onderskeie medewerkers ten opsigte van die aard van betrokkenheid en kontekstualisering. Nie veel van hulle deel die hermeneutiese uitgangspunte van Van Zijl in alle opsigte nie, maar daar is beslis 'n veel groter bewuste poging as in die verlede om met die Suid-Afrikaanse konteks in die interpretasie van die teks rekening te hou. Dit is interessant dat in die bundel Riglyne vir prediking oor vrede daar net twee bydraes oor Matteus opgeneem is. Dit moet egter verstaan word in die lig van die publikasie in dieselfde jaar van die Riglyne vir prediking oor die bergrede waarin heelwat tekste met konsekwensies vir die vredesboodskap aan die orde kom.

In die Riglyne vir prediking oor die bergrede val dit op dat die Suid-Afrikaanse konteks tog in verskillende bydraes aan die orde kom. By wyse van illustrasie kan gewys word op Cloete wat na aanleiding van Mt 5:5 en 6 na die kwessie van geweld en vreedsame protes in Suid-Afrika verwys, asook die gevaar van die verideologisering van geregtigheid in Suid-Afrika in 'n konteks waar dit so ter sake is om die belang van reg en geregtigheid te onderstreep (Burger, Müller \& Smit 1990a:65w; 71vv). Nicol stel in 'n bespreking van Mt 5:9 die Suid-Afrikaanse konteks heel pertinent aan die orde en beklemtoon dat die kerk die stryd nie net van een kant kan sien nie, maar ook nie bloot 'n middeweg of neutrale balans tussen strydende partye kan handhaaf nie. 'Almal wat vrede probeer maak waar daar vyandskap is, stel hulle in die vuur tussen die twee strydende partye' (Burger, Müller \& Smit 1990a:101). Die waarheid van hierdie uitspraak word in ons tyd tragies genoeg daagliks in Suid-Afrika en ander konflikareas in die wêreld konkreet beleef, selfs deur medewerkers aan die betrokke bundel riglyne. 
Nog ' $n$ voorbeeld is Smit wat in sy bespreking van Mt 6:5-9 (Burger, Müller \& Smit 1990a:157v) sensitiwiteit openbaar vir die perspektief van die feministiese teologie, terwyl Durand in sy bespreking van die implikasies van die boodskap oor versoening daarvoor aandag vra dat die prediking oor die versoening anders sou verloop in die Nederduitse Gereformeerde Kerk as in die Nederduitse Gereformeerde Sendinkerk.

Prediking in en aan die NGK sal baie meer pertinent die skuldvraag in die versoeningsproses aanspreek vanuit die hoek van diegene wat die onreg pleeg of gepleeg het of toelaat dat dit gepleeg word. Daarteenoor sal die prediking in die NGSK meer die klem laat val op die versoening ten spyte van die skuldvraag. In beide gevalle sal die voorrang van die versoening soos uitgedruk in die sleutelverse (23-24) egter onomwonde na vore moet kom.

(Burger, Müller \& Smit 1990a:129)

Müller weer onderstreep dat die harde werklikheid van die gebod tot vyandsliefde in die Suid-Afrikaanse konteks gestalte moet vind in die vredesgroet en gebed vir die "ander een": die terroris, die betoger en die onderdrukker; die kommunis en die kapitalis...' (Burger, Müller \& Smit 1990a:140). In alle billikheid moet daarop gewys word dat daar nog steeds bydraes is waarin die Suid-Afrikaanse konteks weinig of glad nie figureer nie, selfs in die geval van tekste waar dit met reg verwag sou kon word, soos Mt 5:7 waar dit oor die barmhartigheid gaan (vgl Burger, Müller \& Smit 1990a:77vv).

In die Riglyne vir prediking oor vrede gee Boesak 'n gebalanseerde en nugtere uiteensetting van die intog van Jesus in Jerusalem volgens Mt 21:12-17. Sonder om die geweldadige aard van die tempelreiniging enigsins af te swak, plaas hy dit tog in die regte perspektief deur af te wys dat daar enige etiek van oorlog, selfverdediging of rewolusie daarop gebou kan word (Burger, Müller \& Smit 1990b:219). Hy onderstreep wel in geen onsekere terme nie die implikasies hiervan ten opsigte van die handhawing van geregtigheid en die protes teen skeiding. 'Dit is onuithoudbaar dat die NG Kerk 'n "familie" is' (Burger, Müller \& Smit 1990b:224).

Die bydrae van Van Zijl in dieselfde bundel oor Mt 18:15-20 stel die kwessies van kerklike tug aan die orde, maar veral ook die betekenis hiervan vir gewone lidmate. Tereg word hier klem gelê op die verantwoordelikheid van elke gelowige 'om vrede te skep waaı die sonde so dikwels 'n slagveld van menslike verhoudings maak' (Burger, Müller \& Smit 1990b:212). Tog moet opgemerk word dat, hoewel hy na die tugreglement van die Nederduitse Gereformeerde Kerk verwys, 'n konsekwente betrokke lees van die teks nie plaasvind nie. 
Hierdie opmerking doen natuurlik niks af aan die waarde van selfstandige navorsing oor Mt 18:15-20 met die oog op die kerklike tug nie. In 'n artikel vat Van Zyl (1988) die vernaamste bevindinge saam van sy diachroniese en sinchroniese navorsing oor hierdie gedeelte in sy proefskrif (Van Zyl 1987). Enkele sake wat hieruit na vore kom: teologies staan hierdie gedeelte nader aan die kollektiewe tuguitoefening, hoewel dit die spore toon van 'n moontlike diskussie rondom die verampteliking van die tug. Daarom is dit belangrik dat die klem in Matteus nie op die prosedure val nie, maar op die terugwen van die sondaar. Terwyl die kerk volgens Matteus 'n corpus mixtum van ware en onegte gelowiges is, moet die tug as suiwerende handeling en as die kerk se manier om die bose in sy midde te beveg, gesien word. Verder is die tug 'n heilbrengende, gemeentelike en koninkrykshandeling (Van Zyl 1988:87, 91v).

In hierdie verband is dit ook verblydend om te let op die grondige wyse waarop deur kerkregtelikes met die Skrifgegewens omgegaan word. 'n Mens het groot waardering vir die intensiewe wyse waarop Coertzen (1985) aan Mt 18:15-35 aandag gee en ook met verskeie Nuwe-Testamentiese eksegete in gesprek tree. Tog val dit op dat hy aandag gee aan spesifieke woorde en frases, maar nie werklik met die breër verband van die hoofstuk en die interne dinamiek daarvan rekening hou nie. Waarskynlik lê die skuld ook voor die deur van die eksegete, maar sy bydrae weerspieël weinig van die resente diskussie en navorsing wat ook plaaslik aan Matteus gewy is.

\section{TEOLOGIE EN ETIEK VAN MATTEUS}

\subsection{Etiek}

In die feesbundel Teologie in konteks wat aan prof Andrie du Toit opgedra is, verskyn daar ook ' $n$ artikel oor die teologie van Matteus. Wanneer hierdie bydrae met dieselfde outeur se vroeëre poging in die Handleiding $I V$ vergelyk word, val 'n paar sake direk op.

In hierdie bydrae word daarvan uitgegaan dat die teologie van Matteus nie so oorwegend deur die titels van Jesus bepaal word nie, maar beslis ook saamhang met die dinamiek van die verhaal as sodanig. Verder word deur die verskillende narratiewe tegnieke in die verhaal nie alleen die karakters in die verhaal aangespreek nie, maar ook die werklike lesers.

'n Volgende moment wat ' $n$ noodsaaklike aanvulling is, is die beklemtoning van die teosentriese moment (Combrink 1991a:4). Dit hang ook saam met 'n narratologiese benadering aangesien die evaluerende perspektief van God self van die grootste belang is vir die verstaan van die verhaal. 
Ook ten opsigte van die Christologie verryk die betekenis van die opbou en vloei van die verhaal die boodskap van Matteus in hierdie verband. In die eerste hoofdeel van die verhaal (Mt 1:1-4:17) word Jesus deur 'n reeks betroubare getuies geïdentifiseer en bekend gestel. In die komplikasie van die verhaal (Mt 4:18-25:46) dui Mt 16:13-20 'n besliste wentelpunt aan. In die resolusie van die verhaal (Mt 26:1-28:20) word Jesus met dramatiese ironie deur teenstanders as Koning en Seun van God aangedui. Verder is die oorheersende perspektief van die implisiete outeur op ideologiese vlak 'dat Jesus die Seun van God is wie se boodskap aanvaar en gehoorsaam moet word' (Combrink 1991a:11). Op verskillende maniere word Jesus in die verhaal uitgebeeld as die Een wat gehoorsaam is en die wil van God doen om sodoende as model vir die implisiete leser te dien. 'n Verdere aksent wat bykom, is die bespreking van die Christologie 'van die kant af'. In aansluiting by die insigte van Malina \& Neyrey (1988:135) word daar gelet op die ideologie en opvattinge van bepaalde karakters wat Jesus op 'n bepaalde wyse evalueer. Algaande word dit duidelik dat die Matteusevangelie ' $n$ herinterpretasie bied van Jesus as afwykende tot die posisie van 'n prominente persoon (Combrink 1991a:18).

Terwyl daar in die verlede reeds uitvoerig oor die belang van die dissipels vir die teologie van Matteus geskryf is, word ook hierdie aspek van die boodskap verryk wanneer rekening gehou word met onder meer die 'gapings' in die teks ten opsigte van die dissipels waardeur die implisiete leser aktief betrek word. Ten diepste teken Matteus dissipelskap nie as lidmaatskap van 'n bepaalde groep nie, maar as die aanvaarding van die norme en waardes wat deur Jesus beliggaam en deur die implisiete outeur aangedien word.

'n Verdere aspek van die teologie van Matteus wat in die bydrae in die Handleiding $I V$ nie aan die orde gekom het nie, is die missionêre dimensie. Dit is nogal 'n opvallende leemte, aangesien die slotperikoop deur die jare as 'n locus classicus met die oog op die sending funksioneer het. Robinson (1986) wys as missioloog daarop dat daar dikwels in die verlede sonder behoorlike aandag aan eksegetiese kwessies deur sendingkundiges van hierdie perikoop gebruik gemaak is. Hierin kom daar egter 'n verandering met die publikasies van Bosch, Du Preez en Robinson self.

In Bosch se Transforming mission (1991) vind verskeie van die suiwer eksegetiese insigte wat hy deur die jare heen benadruk het, opnuut neerslag. Te verwelkom is die beklemtoning dat die slotperikoop nie uit die evangelie as geheel te isoleer is nie (Bosch 1991:57). Verder val dit op dat hy die sosio-kulturele situasie waarin die evangelie tot stand kom, ook wil verreken en daarop wys dat die finale breuk met die Judaïsme waarskynlik nog nie plaasgevind het nie. Oor die hele verskynsel van Joodse bewegings in die eerste eeu sou waarskynlik nog meer genuanseerd gepraat moes word, maar Bosch is kennelik sensitief vir die wyse waarop die Ou Testament in Matteus selfs polemies, maar ook pastoraal en missionêr hanteer kan word (Bosch 1991:59). 
Hy probeer ook verantwoording doen van die inherente spanninge in die teks van Matteus ten opsigte van die beperkte sending aan Israel en die universele heidensending aan die einde. Wanneer Matteus noukeurig gelees word, kom die implisiete leser egter reeds vroeg in die verhaal die verwysings van die verteller na die universele sending teen (vgl Combrink 1991a:28), en is dit miskien nie so onseker as wat Bosch meen nie.

In die historiese konteks van Matteus gaan dit waarskynlik om die saam, naas en eindelik teenoor mekaar staan van die kerk en die sinagoge, dit wil sê die selfverstaan van die Christelike gemeente in samehang met en onderskeie van sy Joodse voorgeskiedenis. In hierdie situasie is die sentrale boodskap van Matteus oor dissipelskap van besondere belang. Wanneer Bosch dus klem lê op die opdrag om dissipels te mak in die laaste opdrag van Jesus, en op die sentrale teologiese betekenis van die doen van die wil van God en die dra van vrugte deur die dissipels van Jesus, is dit wesenlike insigte ten opsigte van die teologie van Matteus. Die sending het vir Matteus te doen met die optrede van Jesus en sy dissipels, trouens daar behoort ook nie teologies tussen die sending van Jesus en die dissipels onderskei te word nie. Dit word dus steeds duideliker dat die aksent van die sending werklik met die geheelkonsepsie van Matteus te make het.

Matteus plaas ' $n$ besondere klem op ortopraksis, op dade in die lewe van dissipels. Dit beteken dissipelskap impliseer liefde en geregtigheid, volkome gehoorsaamheid aan die wil van God. Sending kan dus nie vereng word tot die bybring van heilsekerheid nie, maar behels ook om gelowiges sensitief te maak vir die nood en behoeftes van ander. 'Mission involves, from the beginning and as matter of course, making new believers sensitive to the needs of others, opening their eyes and hearts to recognize injustice, suffering, oppression, and the plight of those who have fallen by the wayside' (Bosch 1991:81).

'n Interessante insig van Bosch raak juis die verskynsel wat in 'n narratologiese benadering van Matteus steeds duideliker word, naamlik die swakheid van die dissipels, die feit dat hulle telkens maar weer nie voldoende insig en begrip toon nie. Hiermee korreleer volgens Bosch (1991:80) 'n bepaalde 'lae' Christologie. Jesus is Immanuel, $\mathrm{Hy}$ is die Een met alle mag wat by hulle in hulle swakheid bly. Dit bly steeds opvallend dat hierdie belofte gegee word net nadat sommige dissipels volgens die verteller (Mt 28:17) nog getwyfel het. Of dit ook beteken dat Immanuel nie hoef terug te kom nie (Bosch 1991:80), is nie so duidelik in die lig van die sterk aksent op die eskatologie in Mt 24-25 nie. Sy insig dat die laaste opdrag aan die einde van die evangelie struktureel die teenpool vorm van die versoeking op die berg $(4: 8 \mathrm{v})$ aan die begin van die eintlike middestuk en hoofdeel van die verhaal, is wel verhelderend. 
Samevattend kan verklaar word dat om dissipels van Christus in en vir die wêreld te wees, die sending is waartoe die kerk van Christus geroep word (Combrink 1991a:28).

\subsection{Etiek}

In die bundel Geloof en opdrag: perspektiewe op die etiek van die Nuwe Testament verskyn daar ook 'n artikel oor die etiek van Matteus onder die titel: 'Die eise van die Regter volgens Matteus' (Combrink 1992). Uit die aard van die saak is daar 'n noue samehang met wat reeds in die navorsing oor die teologie van Matteus bevind is. Tog bring die oogmerke van die bundel mee dat daar weer opnuut na die boodskap van Matteus gekyk word vanuit die perspektief dat daar vanuit 'n bespreking van die etiek van die geskrif met kensketsing van die konteks waarbinne en waarvoor dit geskryf is met ander teoloë en die Suid-Afrikaanse samelewing in gesprek getree moet word.

In aansluiting by Hays (1990:44) word in hierdie bydrae alleen aandag gegee aan die beskrywende en hermeneutiese aspekte van die taak, terwyl die sintese van die etiek van Matteus met dié van ander boeke van die Nuwe Testament nie aandag kry nie.

'n Interessante stelling wat hier gemaak word, is dat etiek nie alleen in die toesprake van Jesus in Matteus aangetref word nie, maar dat die hele verhaal as medium van oorreding dien. Hiermee hang saam dat daar nie alleen gelet word op wat uniek aan Matteus is nie, maar ook op wat gemeenskaplik is met die kultuur van sy tyd, met die simboliese universum waarbinne sy gemeente geleef het. Wanneer die onderskeiding tussen etos en etiek in ag geneem word, sou beweer kon word dat die narratiewe dele van Matteus 'n aanduiding gee van die etos van die gemeente wat in navolging van Jesus gerealiseer moet word, terwyl die toesprake dan die etiek bevat (Combrink 1992:3).

Verder val dit op dat die koninkryk van die hemel veral in die gelykenisse as meestersimbool funksioneer. Verskillende gelykenisse word as voorbeeide bespreek om aan te toon dat die hoorders gedring word om te reageer op die genadige aanbod van die koninkryk, maar ook gewaarsku word en gewys word op die toorn van die Regter waarmee ook rekening gehou moet word.

Aangesien etiek in Matteus veral met die metaforiese verkondiging van die koninkryk saamhang, vloei hieruit voort dat dit ook ten nouste met die eskatologie en Christologie saamhang. Dit kom besonder sterk in die laaste toespraak (Mt 2325) na vore. Hier word beklemtoon dat die dissipels aktief in die hede betrokke moet wees met die oog op die toekoms, terwyl Mt 25:31-46 onderstreep dat waaksaamheid en getrouheid juis in barmhartigheid en liefde gestalte moet vind. 
Tipies van Matteus is natuurlik die etiek van die oorvloediger geregtigheid. Juis daarom bly dit van belang om daarmee rekening te hou dat dit ook in die Bergrede primêr om Christus gaan. In die lig van Mt 5:17-19 se stelling dat Jesus in vervulling laat tree dit waarna die Ou Testament vooruit gewys het, self die kulminasie daarvan is, moet die eis aan die dissipels van kwalitatiewe meerdere getrouheid aan die wet (Mt 5:20) dan verstaan word. Dit wat in Mt 5:20 negatief geformuleer word, word in Mt 5:44 en 48 positief as die gebod tot vyandsliefde en volmaaktheid gestel. Etiek moet gesien word as die relasie tussen wat God in liefde doen en die reaksie van die hoorder op God se heerskappy en op sy eise. 'Once love is seen as the very essence of God, the disclosure of His Kingdom makes love an absolute imperative' (Chilton \& McDonald 1987:38). Terwyl die Bergrede spesifiek met die genadeaankondiging van die saligsprekinge begin, kan in Mt 5:13-16 daartoe opgeroep word dat die geseëndes self ook 'n seën vir die hele wêreld moet wees, en word die imperatief deur die res van die Bergrede en pertinent in die slot (Mt 7:13-27) benadruk.

In hierdie artikel word aan die einde wel gepoog om by die derde dimensie van die etiek, naamlik die hermeneutiese bruglegging na die eie situasie, die versterking van die Christelike praksis in Suid-Afrika, uit te kom. Tog val ook hierdie bydrae in hierdie opsig met reg onder die indringende kritiek van Smit in hierdie selfde bundel: 'Die meeste van die opstelle verteenwoordig nog grootliks 'n binne-gesprek van Nuwe-Testamentici... Dit beteken tegelyk dat dit - amper doelbewus - uiteindelik tog ook nie vir gewone lesers, die 'lidmate' met probleme, geskryf is nie' (Smit 1992:322).

\section{DIE AFRIKA-KONTEKS}

Ofskoon daar in hierdie verband nog heel weinig gedoen is, is daar tog ' $n$ groeiende bewussyn van die noodsaak om te luister na Afrika-teoloë se resepsie van die teks van Matteus. In hierdie verband kan gewys word op die reaksie van Combrink en Müller (1991) op die bydrae van Manus (1991).

Hier word gereageer op Manus se stelling dat die verhoging en status van die tradisionele koningsfiguur in Afrika tot hulp is vir die verstaan van Mt 28:16-20. Terwyl daarmee rekening gehou moet word dat kontekstualisering as 'n metaforiese aktiwiteit aanvaar moet word, moet ook toegegee word dat 'n verantwoorde hermeneutiek tog ook ' $n$ kritiese hermeneutiek moet wees. Daar moet dus daarmee rekening gehou word dat die koningskap van Jesus in Matteus onder meer op ironiese wyse aan die orde kom, omdat Jesus ' $n$ koning beliggaam wat verwerp is, ' $n$ koning wat egter tegelyk ook waarlik dienskneg was. Ofskoon toegegee moet word dat ' $n$ teks beslis beinvloed word deur die diskoers wat die seleksie en ordening van 
spesifieke fasette van die teks bepaal, moet gehandhaaf word dat die teks op sy beurt tog wel ook die diskoers bepaal. Dit neem egter nie weg nie dat in die voortgaande navorsing op Matteus, steeds meer kennis geneem sal moet word van die wyse waarop die leser van Afrika hierdie teks hoor en beleef.

Dit is duidelik dat daar op die gebied van die Matteusnavorsing nog veel te doen is! Moontlik kan die deelnemers aan hierdie konferensie mekaar ook vorentoe weer help om saam met ons onderskeie gespreksgenote en medelesers van die teks in Europa en in Afrika steeds en met meer suiwerheid te luister na en met groter gehoorsaamheid te reageer op die ou en nuwe skatte wat ons met mekaar saam uit hierdie aangrypende verhaal oor Jesus in ons eie tyd en konteks na vore mag bring.

\section{Literatuurverwysings}

Bosch, D J 1991. Transforming mission: Paradigm shifts in theology of mission. New York: Orbis.

Burger, C W, Müller, B A \& Smit, D J (red) 1990a. Riglyne vir prediking oor die bergrede. Kaapstad: N G Kerk-uitgewers. (Woord teen die Lig II/5.)

_ 1990b. Riglyne vir prediking oor vrede. Kaapstad: N G Kerk-uitgewers. (Woord teen die Lig III/1.)

Chilton, B \& McDonald, J I H 1987. Jesus and the ethics of the Kingdom. Grand Rapids: Eerdmans.

Coertzen, P 1985. Matteus 18:15-35 as reg vir die Nederduitse Gereformeerde Kerk, in Louw, D J (red), Op die breuklyn, 65-82. Kaapstad: NG Kerk-uitgewers.

Clark, D J \& De Waard J 1982. Discourse structure in Matthew's gospel. Scriptura $5,1-97$.

Cloete, G D 1985. In the meantime, trouble for the peacemakers: Matthew 5:10-12. $J T h S A$ 52, $42-48$.

Combrink, H J B 1979. Die vervulling van die Ou Testament in die Matteusevangelie, in Odendaal, D J, Müller, B A \& Combrink, H J B (reds), Die Ou Testament vandag, 51-63. Kaapstad: N G Kerk-uitgewers.

- 1982. The macrostructure of the Gospel of Matthew. Neotestamentica 16, 120.

- 1983. The structure of the Gospel of Matthew as narrative. Tyndale Bulletin 34, 61-90.

- 1987a. Matteus 13:44-50, in Burger, C W, Müller, B A \& Smit, D J (reds), Riglyne vir die prediking oor die gelykenisse en wonderverhale, 49-60. Kaapstad: NG Kerk-uitgewers. (Woord teen die lig II/2.). 
Combrink, H J B 1987b. Matteus 25:14-30, in Burger, C W, Müller, B A \& Smit, D J (reds), Riglyne vir prediking oor die gelykenisse en wonderverhale, 69-82. Kaapstad: NG Kerk-uitgewers. (Woord teen die lig II/2).

- 1988a. Strukturalisme - is 'n herwaardering nodig? NGTT 29, 129-138.

- 1988b. Die funksie van die saligsprekinge in die Bergrede, in Coetzee, J C (red), Koninkryk, Gees en Woord: Huldigingsbundel aungebied aan prof dr Lambertus Floor, 180-198. Pretoria: N G Kerkboekhandel.

- 1988c. Die Evangelie volgens Matteus: Inleiding en teologie, in Du Toit A B (red), Die Sinoptiese Evangelies en Handelinge: Inleiding en Teologie, 59-105. Pretoria: N G Kerkboekhandel. (Handleiding by die Nuwe Testament IV.)

- 1991a. Dissipelskap as die doen van God se wil in die wêreld, in Roberts, J H, Vorster, W S, Vorster, J N, Van der Watt, J G (reds), Teologie in konteks, 1-31. Halfway House: Orion.

- 1991b. Die Bybel lewe in Afrika. Acta Theologica 11/2, 81-90.

- 1992. Die eise van die regter volgens Matteus. Scriptura S9a, 1-23.

Combrink, H J B \& Müller, B A 1991. The gospel of Matthew in an African context: In dialogue with Chris Manus. Scriptura 39, 43-51.

De Villiers, P G R 1982. Configuration and plot in Mt 19-22: Aspects of the narrative character of the Gospel of Matthew. Neotestamentica 16, 56-73.

Domeris, W R 1990. Exegesis and proclamation: 'Blessed are you...' (Matthew 5:112). $J T h S A$ 73, 67-76.

Du Plessis, J G 1985. Clarity and Obscurity: A study in textual communication of the relation between sender, parable and receiver in the Synoptic Gospels. DTh-thesis, University of Stellenbosch.

Durand, J J F 1990. Matteus 5:21-26, in Burger, Müller \& Smit 1990a:124-131.

Du Toit, A B 1966. The nature and witness of the church in the world according to Mt 5:13-16. Biblical Essays: Proceedings of the ninth meeting of Die OuTestamentiese Werkgemeenskap in Suid-Afrika held at the University of Stellenbosch, 26th-29th July 1966 and proceedings of the second meeting of Die Nuwe-Testamentiese Werkgemeenskap van Suid-Afrika held at the University of Stelenbosch, 22nd-25th July 1966, 200-218. Potchefstroom: Pro Rege. (Forthcoming), 200-218.

- 1967. The self-revelation of Jesus in Matthew 5-7. Neotestamentica 1, 66-72.

- 1986. Enkele gedagtes oor Matteus se gebruikmaking van die Ou Testament in Matteus 2:15. HTS 42, 386-395.

Frankemölle, H 1974. Jahwebund und Kirche Christi: Studien zur Form- und Traditionsgeschichte des 'Evangeliums' nach Matthäus. Münster: Aschendorff. (Neutestamentliche Abhandlungen 10.) 
Hays, R B 1990. Scripture-shaped community: The problem of method in New Testament ethics. Interpretation 44, 42-54.

Hill, D 1979. Some recent trends in Matthean studies. Irish Biblical Studies 1, 139149.

Jacob, S 1987. Southern Africa Today. Refugees and exiles: A challenge to the churches. JThSA 61, 59-72.

Kingsbury, J D 1975. Matthew: Structure, christology, kingdom. Philadelphia: Fortress.

Koekemoer, P J T 1971-72. Die getuienis van die evangelie volgens Mattheus oor die maagdelike geboorte van Jesus Christus. HTS 28, 63-87.

Kodjak, A 1986. A structural analysis of the sermon on the mount. Berlin: Mouton. (Religion and reason 34. )

Leech, G N 1983. Principles of pragmatics. London: Longman. (Longman Linguistics Library 30.)

Louw, J P 1982. Semantics of New Testament Greek. Philadelphia: Fortress. (SBL Semeia Studies.)

Maartens, P J 1977. The cola structure of Matthew 6. Neotestamentica 11, 48-76.

Malina, B J \& Neyrey, J H 1988. Calling Jesus names: The social value of labels in Matthew. Sonoma: Polebridge.

Manus, C 1991. King-Christology. Scriptura 39, 25-42.

Robinson, P J 1986. Matteus 28:16-20 in die ontwikkelende sendingdenke van die Nederduitse Gereformeerde Kerk, in Du Preez, J, Pauw, C M \& Robinson, P J (red), Sendinggenade - Feesbundel vir WJ van der Merwe, 86-101. Bloemfontein: NG Sendinguitgewers.

Suggit, J 1988. Exegetical comment: Comrade Judas: Matthew 26:50. JThSA 63, 5658.

Van Aarde, A G 1980a. 'n Nuwe benadering tot 'Gattungsforschung'. HTS 36/1 \& 2, 58-73.

- 1980b. 'Betekenis' en 'gebruik' in die makarismereeks (Matt 5:3-10). HTS 36/3 \& 4, 1-28.

- 1980c. Die bruikbaarheid van die aktante-analise vir die eksegese van Sinoptiese tekste. HTS 36/3 \& 4, 29-49.

- 1982a. 'n Ondersoek na die Nuwe-Testamentiese makarisme en makarismereeks as Gattung. HTS 38/1, 36-52.

- 1982b. Matthew's portrayal of the disciples and the structure of Mt 13:5317:27. Neotestamentica 16, 21-34.

— 1982c. God met ons: Dié teologiese perspektief van die Matteusevangelie. DD-proefskrif, Universiteit van Pretoria. 
Van Aarde, A G 1984. Verlede en hede op die gebied van die Matteusnavorsing: 'n Oorsig van die verskillende interpretasiemodelle. Scriptura 11, 1-49.

- 1986. Die wonderbaarlike vermeerdering van brood (Matt 14:13-21 en par): Historiese kritiek in perspektief. HTS 42, 229-256.

- 1987. Immanuel as die geïnkarneerde tora: Funksionele Jesusbenaminge in die Matteusevangelie as vertelling. HTS 43, 242-277.

Van Tilborg, S 1986. The sermon on the mount as an ideological intervention: $A$ reconstruction of meaning. Assen: Van Gorcum.

Van Zijl, H J 1991. Die Bergrede as Littérature Engagée. DTh-proefskrif, Universiteit van Stellenbosch.

Van Zyl, H C 1982. 'n Moontlike verklaring vir Mt 7:6. Theologia Evangelica 15, 67-82.

- 1987. Matteus 18:15-20: 'n Diachroniese en sinchroniese ondersoek met besondere verwysing na kerklike dissipline. DD-proefskrif, Universiteit van Pretoria.

- 1988. Matteus 18:15-20: 'n Diachroniese en sinchroniese ondersoek met besondere verwysing na kerklike dissipline. Skrif en Kerk 9/1, 75-92.

Vorster, W S 1971. Matt 12:38vv en die historisiteit van die gegewens in Jona. Theologia Evangelica 4, 223-235.

- 1977. The structure of Matthew 13. Neotestamentica 11, 130-138.

- 1982. De structuuranalyse, in Klijn, A F J (red), Inleiding tot de studie van het Nieuwe Testament, 127-152. Kampen: Kok.

- 1985. Gelykenisse in konteks: Matteus 13 en die gelykenisse van Jesus. HTS 41, 148-165.

- 1988. Die Evangelie volgens Markus: Inleiding en teologie, in Du Toit, A B (red), Die Sinoptiese Evangelies en Handelinge: Inleiding en Teologie, 106-150. Pretoria: N G Kerkboekhandel. (Handleiding by die Nuwe Testament IV.)

Willemse, W L 1985. Die Ou Testament as verwysingsraamwerk vir die evangelie volgens Matteus. MA-verhandeling, UWK. 